\title{
A Preliminary Study on Heavy Metal Concentration in the Marine Bivalves Marcia Marmorata Species and Sediments Collected From the Coastal Area of Kuala Perlis, North Of Malaysia
}

\author{
Lias, K, Jamil T, Nor Aliaa, S \\ Center of Ocean Research, Conservation \& Advances (ORCA) Division of Research, Industrial Linkage, \\ Community network \& Alumni Universiti Teknologi MARA (Perlis) 02600 Arau Perlis, Malaysia
}

\begin{abstract}
Aquatic organism and sediment absorb heavy metal from surrounding and accumulate in their body tissues and its surface area. The tissue of Marcia Marmorata sp. is being relatively eaten by the local people as other marine organism along the coastal area of Kuala Perlis. The tissue and sediment samples collected at four stations in Kuala Perlis Coast were analyzed for heavy metals by using an Inductively Coupled Plasma Mass Spectrometry (ICP-MS). The bioaccumulation of metal in the soft tissue exhibit the following decreasing order: $\mathrm{Zn}>\mathrm{Cu}>\mathrm{As}>\mathrm{Cd}$ while the mean concentration of heavy metal in sediment showed the following trend: $\mathrm{Zn}>\mathrm{Cu}>\mathrm{Cd}>\mathrm{As}$. The mean concentration of Arsenic (As), Cadmium (Cd) and Copper (Cu) in the tissue was exceeded the permissible limit except for Zinc (Zn) when compared to the FAO/WHO 2004 as well as Food Regulation 1985. Therefore it can be generalized that bivalve from the Coastal area of Kuala Perlis are not safe to consume in terms of these heavy metal concentration and constitute a risk for human health. Two-way ANOVA test indicated statistically significant differences $(p<0.05)$ between sampling stations in the concentration of $\mathrm{Zn}$ while between the bivalve tissue and sediment indicated significance difference for As. Correlation coefficient were calculated to study the sediment and bivalve tissue relationship, which shows that there are no significance correlation among these metals, indicating that tissue of Marcia Marmorata sp. tend to regulate the levels of heavy metals in their tissue and may not reflect the levels in sediment to which there are exposed
\end{abstract}

Keywords- Bioaccumulation, Heavy metals, Bivalves, correlation coefficient, ICP-MS.

\section{Introduction}

The increases in anthropogenic activities contribute to the accumulation of hazardous chemicals such as heavy metals, in the environment (Ahmad Ismail., 2006). Heavy metal has been recognized as one of the important pollutants posing a threat to the marine organism (Al-Yousuf et al., 2000). These metals were taken up by the aquatic organism directly through their exposed tissues and through feeding (Chapman et al., 1998, Fukunaga et al., 2011) and many marine estuarine are known to accumulate heavy metal from water and their food which tend to concentrate along the food chain (Ndome et al., 2010). The abundance of heavy metal may jeopardize human health due to the consumption of contaminated bivalves (Stanciu et al., 2005; Gabr et al., 2008). For examples, As may cause skin cancer, (Järup., 2003); Pb can damage blood circulation (Kamaruzzaman et al., 2011) and excessive intake of Zn may cause electrolyte imbalance, and lethargy (Chinnaraja et al., 2011). Marcia Marmorata sp. is one of the mollusks that have the characteristic of filter feeders which can accumulate the heavy metal. This species can be found in burrows in muddy and sandy-cummuddy bottoms at 0-m tidal level (Jahangir. S et al., 2012) and has been used to assess the environmental conditions of coastal aquatic environments (Liang et al., 2004; Silva et al., 2006; Alfonso et al., 2008). Besides mollusk, heavy metal also can accumulate in the sediment and the level of heavy metal in sediment can be used an indicator for monitoring of pollution levels (Cobela-Garcie and Prego, 2003; Muohi et al., 2003; Wan Mohd Razi Idris et al., 2009). According to the Inengite et al. (2010), heavy metal discharged into the environment rapidly associates with particulates and ultimately settles in bottom sediments of water bodies either direct discharge or surface run-offs. The main objective in this work is to study the concentration of heavy metal in mollusk Marcia Marmorata sp. and sediment along coastal area of Kuala Perlis, Perlis and to study the correlation between the tissue of bivalve, Marcia Marmorata sp. and the sediment.

\section{Methodology}

In this research study, there are four sampling location chosen along the coastal area of Kuala Perlis as showed in figure 1 below:- 


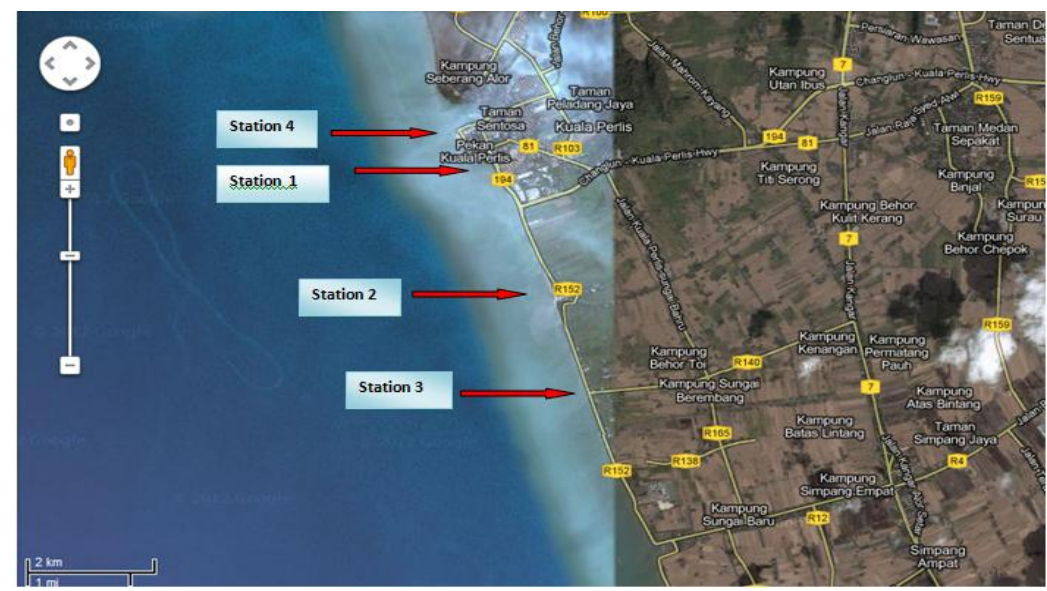

Figure 1: The sampling Location along the Coastal Area of Kuala Perlis, Perlis

The study area is within Kg Sungai Ketam to Kg. Sungai Berembang along the coastal area of Kuala Perlis were choose due to the presence of anthropogenic activities that contribute to heavy metal such as ferry services, boat activities, power plant, paddy field, fish landing and residents area. The tissue of Marcia Marmorata sp. and sediment samples are taken together within $1 \mathrm{~km}$ from each station. The average sizes of the Marcia Marmorata $s p$. taken in this study are $39-70 \mathrm{~mm}$ (S. Jahangir et al., 2012) A total 50 to 100 specimens of similar sized Marcia Marmorata sp. were collected randomly, and stored in plastic bag and iced prior to laboratory analysis. Samples, bivalve tissue and sediment were dried at $80^{\circ} \mathrm{C}$ for 72 hours, grind and sieving the sample through $63 \mu \mathrm{m}$ mesh size. Approximately $0.05 \mathrm{~g}$ of dried tissues of Marcia Marmorata sp. was digested with $3 \mathrm{~mL}$ of concentrated $65 \%$ nitric acid, $\mathrm{HNO}_{3}$ and $1 \mathrm{~mL}$ of $30 \%$ hydrogen peroxide, $\mathrm{H}_{2} \mathrm{O}_{2}$ in a Teflon bomb. The digestions of tissue were conducted together with the sediment to ensure the accuracy of the result and to avoid the error during the experiment. The digestion method involve the heating of 50mg of a less than $63 \mu \mathrm{m}$ size sample in a sealed Teflon vessel with mixed concentrated acid $\mathrm{HF}, \mathrm{HNO}_{3}$ and $\mathrm{HCl}$ in the ratio of 3.0: 3.5: 3.5 . The Teflon vessels were kept at $160^{\circ} \mathrm{C}$ for 5 hours in the oven. After cooling, the mixed solution of EDTA and Boric acid was added and the vessels again were heated at $160^{\circ} \mathrm{C}$ for at least 5 hours. After cooling at room temperature, the content of the vessel were transferred $10 \mathrm{~mL}$ polypropylene test tube and was diluted to $10 \mathrm{~mL}$ with deionized water (Kamaruzzaman et al., 2011). The heavy metal levels were then determined by using the inductively Coupled Plasma Mass Spectrometry (ICP-MS).

\section{Result and Discussion}

The concentration of heavy metal in the tissue of Marcia Marmorata and sediment were compared with the permissible limit suggested by FAO/WHO and USEPA guidelines. Pollution Load Index (PLI) and Geo-Accumulation index was used to assess the contamination in the soft tissue of M. Marmorata $s p$ and sediment. Lastly, Pearson's Correlation Coefficient was measured in order to know the relationship between the sediment and the bivalve of M. Marmorata sp. The validity of the method used was checked using the International Certified References Material, CRM DORM-3 (Fish protein) by National Research Council of Canada and a blank were used as a quality control. While for the sediment, Standard References Material SRM 1646a (estuarine sediment) from National Institute of Standard and Technology was used. The recovery test for tissue of M. Marmorata sp. and sediment were ranged from $76 \%$ to $144 \%$ and $71 \%$ to $132 \%$ respectively and were illustrated in the table 1.

\begin{tabular}{|c|c|c|c|c|c|c|}
\hline \multirow[t]{3}{*}{ Element } & \multicolumn{6}{|c|}{ Heavy Metal Concentration (mg/kg dry weight) in reference materials } \\
\hline & \multicolumn{3}{|c|}{$\begin{array}{l}\text { (DORM-3) analyzed together with tissue } \\
\text { sample. }\end{array}$} & \multicolumn{3}{|c|}{$\begin{array}{l}\text { (SRM 1646a) analyzed together with } \\
\text { sediment sample }\end{array}$} \\
\hline & $\begin{array}{l}\text { Certified } \\
\text { Values }\end{array}$ & $\begin{array}{c}\text { Measured } \\
\text { value }\end{array}$ & $\begin{array}{l}\text { Recovery } \\
\text { Test }(\%)\end{array}$ & $\begin{array}{l}\text { Certified } \\
\text { Values }\end{array}$ & $\begin{array}{c}\text { Measured } \\
\text { value }\end{array}$ & $\begin{array}{l}\text { Recovery } \\
\text { Test }(\%)\end{array}$ \\
\hline Arsenic (As) & $6.88 \pm 0.30$ & 5.9804 & 86.92 & $6.23 \pm 0.21$ & 7.756 & 124.49 \\
\hline $\begin{array}{l}\text { Cadmium } \\
(\mathrm{Cd})\end{array}$ & $\begin{array}{c}0.290 \pm \\
0.020\end{array}$ & 0.256 & 88.19 & $\begin{array}{c}0.148 \pm \\
0.007\end{array}$ & 0.1062 & 71.79 \\
\hline Copper $(\mathrm{Cu})$ & $15.5 \pm 0.03$ & 22.4 & 144.81 & $10.01 \pm 0.34$ & 13.3 & 132.52 \\
\hline Zinc (Zn) & $51.3 \pm 3.1$ & 39.1 & 76.16 & $48.9 \pm 1.6$ & 58 & 118.54 \\
\hline
\end{tabular}


Table 1: Heavy metal concentrations (mg/kg dry weight) in reference materials (DORM-3) and (SRM 1646a) analyzed together with tissue sample and sediment respectively.

Meanwhile, the distribution of heavy metal in tissue sample of Marcia Marmorata sp. and sediment were expressed in the table 2 and figure $1(\mathrm{a}-\mathrm{b})$ below.

\begin{tabular}{|l|l|l|l|l|l|l|l|l|}
\hline \multirow{3}{*}{ Station } & \multicolumn{9}{c|}{ Heavy metal (mg/kg dry weight) } \\
\cline { 2 - 10 } & \multicolumn{2}{|c|}{ As } & \multicolumn{2}{c|}{ Cd } & \multicolumn{2}{c|}{ Cu } & \multicolumn{2}{c|}{ Zn } \\
\cline { 2 - 9 } & Sediment & Tissue & Sediment & Tissue & Sediment & Tissue & Sediment & Tissue \\
\hline S1 & 0.0016 & 20.4 & 0.0934 & 3.4 & 38.9 & 22.8 & 141.3 & 88.7 \\
\hline S2 & 0.0025 & 21.2 & 0.0945 & 1.9 & 21.8 & 14.9 & 130.3 & 77.5 \\
\hline S3 & 0.0019 & 24.0 & 0.0790 & $7.1^{*}$ & 23.3 & 23.9 & 105.1 & 89.7 \\
\hline S4 & 0.0015 & 16.5 & 0.1250 & 5.2 & 83.4 & 24.7 & 107.3 & 116.5 \\
\hline Mean & 0.0075 & 20.53 & 0.098 & 4.40 & 41.85 & 21.58 & 121.0 & 93.1 \\
\hline SD & 0.0065 & 3.10 & 0.0194 & 2.249 & 28.76 & 4.518 & 17.69 & 16.55 \\
\hline
\end{tabular}

Table 2 Metal concentration in sediment and bivalve tissue in ( $\mathrm{mg} / \mathrm{kg}$ dry weight) at Kuala Perlis coastal area.

\section{Bivalve of Marcia Marmorata sp.}

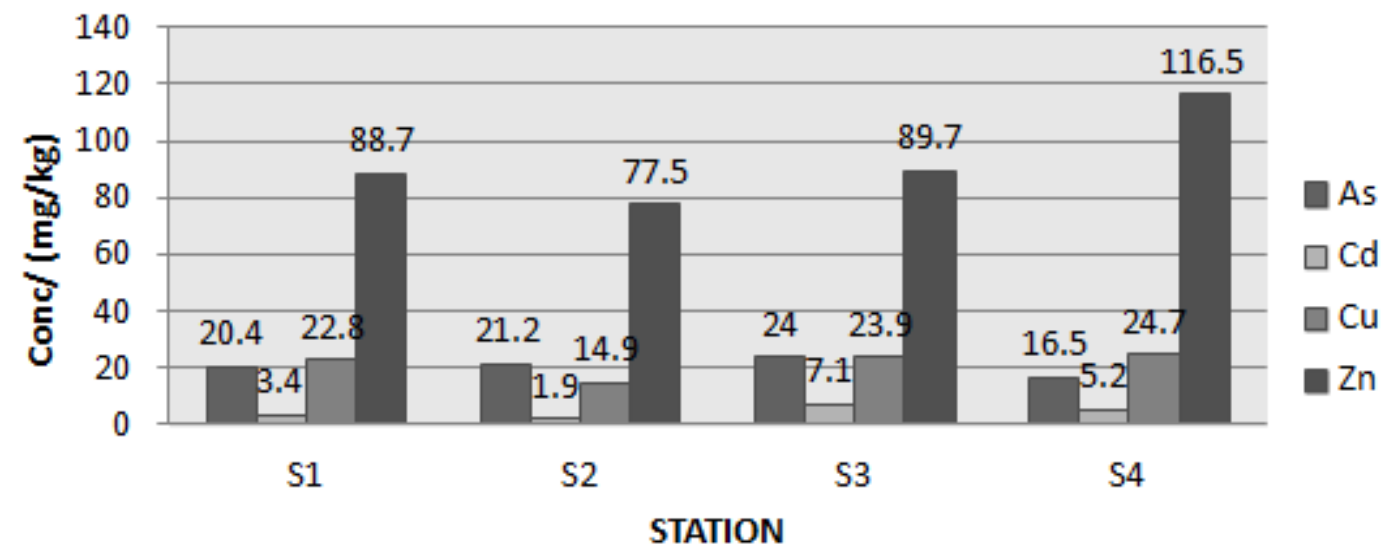

(a): Graph for tissue

\section{Sediment $(\mathrm{mg} / \mathrm{kg})$}

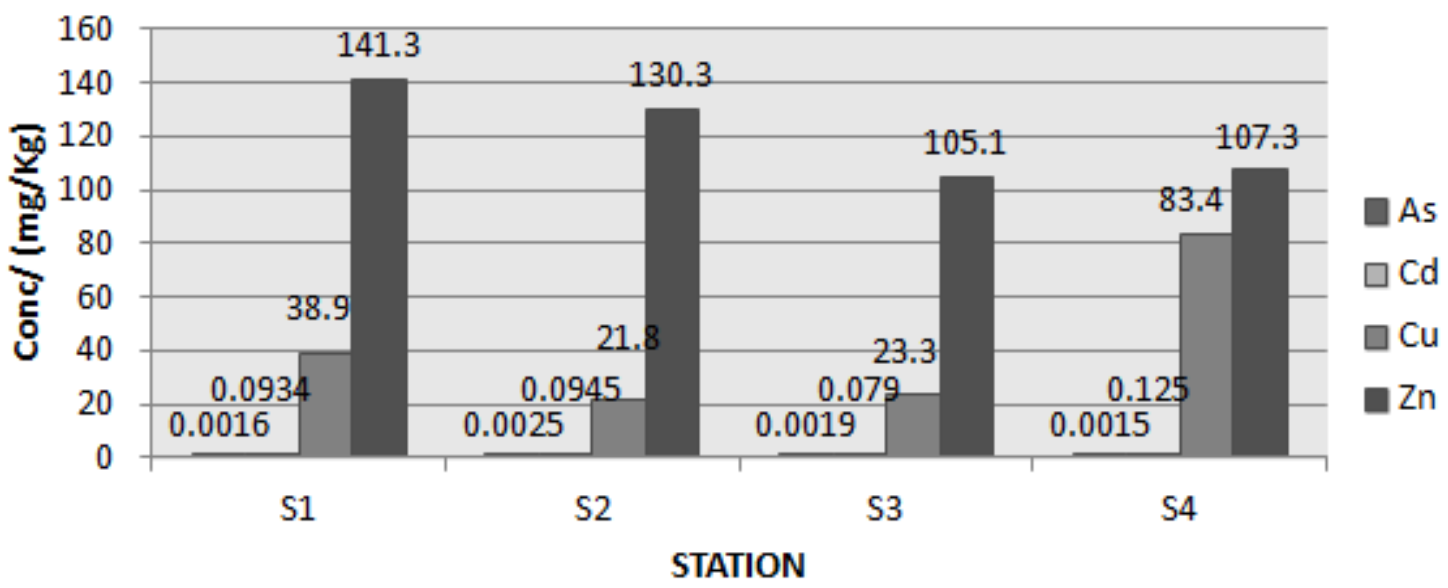

(b): Graph for Sediment

Figure $1(a-b)$ : Distribution of heavy metal in Tissue and sediment

Generally, $\mathrm{Zn}$ showed the highest concentration in both sediment and tissue compared to the other metals. The decreasing order based on mean concentration in sediment showed that $\mathrm{Zn}>\mathrm{Cu}>\mathrm{Cd}>\mathrm{As}$ while in tissue was $\mathrm{Zn}>\mathrm{Cu}>\mathrm{As}>\mathrm{Cd}$. In sediment, $\mathrm{Zn}$ concentration is from $105.1-141.3 \mathrm{mg} / \mathrm{kg}$ with the highest concentration recorded in ST1. Meanwhile the As recorded the most lowest concentration with the value of $0.0015 \mathrm{mg} / \mathrm{kg}$ at ST4.

Meanwhile, $\mathrm{Cu}$ gave slightly higher concentration in sediment and tissue at station 4 with the value of 83.4 and $24.7 \mathrm{mg} / \mathrm{kg}$ respectively. The major contribution of high value in copper is because copper may present due to urban runoff, industrial effluents and wastewater (Kamaruzzaman et al., 2011). Statistical analysis (two-way 
ANOVA) indicated that for heavy metal $\mathrm{Cd}$ and $\mathrm{Cu}$, they are both had no significant differences between sampling station and also between sediment and bivalve tissue ( $p>0.05$ ). While for As, two-way ANOVA found that they are significant differences between the sediment and tissue $(\mathrm{p}<0.05)$. This indicated that the concentration of As in sediment was correlated with the bivalve tissue Marcia Marmorata sp. As overall, Zinc was the highest uptake in the sediment especially in estuaries area because the concentrations of suspended particles are greater, thus greater proportion of the zinc is adsorbed to suspended particles (Ahumada R. et al., 2007).

Meanwhile, the highest concentration of heavy metal accumulated in the tissue of M. Marmorata sp. was $\mathrm{Zn}$ with the value of $116.5 \mathrm{mg} / \mathrm{kg}$ while the lowest concentration was $\mathrm{Cd}$ with value $1.9 \mathrm{mg} / \mathrm{kg}$. This may be from anti-fouling paint and incidental discharges of fuel, oil from boats, ship and also municipal sewage as mentioned by Waznah et al., (2011). In addition this was supported by Velasquez et al., 2002 in which they said the shipyard in the middle of river might be utilizing materials that are high in $\mathrm{Zn}$. Cadmium has the lowest concentration and this may be due to fairly mobile during the tropical weathering thus contributed to the lower concentration in the tissue of M. Marmorata sp. as proposed by Olade M.A, (1987). The level of metal concentration in marine species like M. Marmorata were varies due to the fact that every species has different mechanism for metal binding and regulation (Yap et al., 2004; Nur Atiqah et al., 2011). Arsenic (As) concentration was higher in tissue compared to sediment and this indicate the influence of aquatic environments (Zhang and Wang, 2007) and surrounding human activities at specific point of time may contribute to accumulation of heavy metal in the fishery products (Alina M, 2012). Since at surrounding of the station 3 and 4 consist of paddy field, it is believed the pesticides and herbicides were used thus lead to the arsenic contamination in the sea, accumulate in sediment and bivalve tissue as mention by Andrew Rumsby, 2011.

The concentration of cadmium was from $1.9-7.1 \mathrm{mg} / \mathrm{kg}$ probably related with the paddy field existence within the stations as cadmium was easily taken up by plants and transported to different organs although it had no beneficial effects to plants and animals. The higher value in $\mathrm{Cu}$ may come from the paddy field activities which they used pesticides to prevent the insects attack. The pesticides may contain copper salt that lead to the accumulation (Sofia, 2005) into the bivalve mollusk Marcia Marmorata sp.

Zinc recorded the highest value of mean concentration for both sediment and tissue which is 121.0 and $93.1 \mathrm{mg} / \mathrm{kg} \pm 16.55 \mathrm{mg} / \mathrm{kg}$ respectively. Station 1 for sediment and station 4 for tissue were determine to accumulate the high value of zinc element with concentration 141.3 and $116.5 \mathrm{mg} / \mathrm{kg}$ respectively. The location of station 1 and station 4 were close to boating activities, fish landing, restaurants, and sightseeing view place and mosque. Kamaruzzaman et al., (2011) stated that $\mathrm{Zn}$ has been used as an anti-corrosion agent and its ability to get speedy oxidation might enhance the level of zinc in the Kuala Perlis. This will tend the organism to accumulate the high amount of $\mathrm{Zn}$ in its soft tissue. The concentration (in $\mathrm{mg} / \mathrm{kg}$ ) of heavy metal in this study was compared to the recommended permissible limit of standard references which is basically from FAO/WHO and Malaysian Food regulation 1985 and PTWI. The comparisons were shown in table 3.

\begin{tabular}{|c|c|c|c|c|}
\hline \multirow{2}{*}{ Location } & \multicolumn{4}{|c|}{ Heavy Metal Concentration (mg/kg dry weight ) } \\
\cline { 2 - 5 } & As & Cd & Cu & Zn \\
\hline S1 & 20.4 & 3.4 & 22.8 & 88.7 \\
\hline S2 & 21.2 & 1.9 & 14.9 & 77.5 \\
\hline S3 & 24.0 & 7.1 & 23.9 & 89.7 \\
\hline S4 & 16.5 & 5.2 & 24.7 & 116.5 \\
\hline Mean & $20.53 \pm 3.10$ & $4.4 \pm 2.249$ & $21.58 \pm 4.518$ & $93.1 \pm 16.55$ \\
\hline $\begin{array}{c}\text { FAO/ WHO } \\
\text { (mg/kg) }\end{array}$ & $0.1-5.0$ & 0.2 & 10.00 & 150 \\
\hline $\begin{array}{c}\text { Malaysian Food } \\
\text { and Regulation } \\
(\mathrm{mg} / \mathrm{kg})\end{array}$ & 1.0 & 1.0 & 30.00 & 100 \\
\hline
\end{tabular}

Table 3: The comparison of the concentration $(\mathrm{mg} / \mathrm{kg}$ ) of $\mathrm{As}, \mathrm{Cd}, \mathrm{Cu}$ and $\mathrm{Zn}$ in homogenized tissue of Marcia Marmorata $s p$. with the recommended permissible limit.

Based on table 3, the results indicated that the mean concentration of As and $\mathrm{Cd}$ exceeded the maximum permissible levels (MPLs) according to the codes of FAO/WHO (1982) and Malaysian Food Regulation (1985). Meanwhile mean concentration of $\mathrm{Cu}$ exceed the permissible limits set by the FAO which is $10.00 \mathrm{mg} / \mathrm{kg}$ but were within the regulated limit $30.00 \mathrm{mg} / \mathrm{kg}$ set by the Malaysian Food regulation (1985). Zinc were determined exceeded the maximum permissible limit of the regulation set by Malaysian Food Regulation and in acceptable limit that set up by FAO/WHO. This showed that the consumption of the bivalve tissue of M. Marmorata $s p$. will pose risk to human health. Hence a periodic monitoring of these metals in the tissue of this species is 
recommended. The relationship ( $\mathrm{r}$ ) between the metal content in sediment and bivalve tissue were carried out using the Pearson Correlation Coefficients. The correlation of $\mathrm{As}, \mathrm{Cd}, \mathrm{Cu}$ and $\mathrm{Zn}$ concentrations between those in the sediment and that in the bivalve tissue of Marcia Marmorata sp. were calculated and it was found that there was no statistically significant correlation (Pearson's $r, p>0.05$ ) between these components. This indicates that the amount of metal in the sediment cannot be directly reflected in the tissue (Lau et al., 1998) of Marcia Marmorata sp. They are several factor that may influenced the bioaccumulation of heavy metal in sediment and bivalve tissue, such as their feeding habit, growth rate and age of the organism (Lau et al., 1998).

Then, for the sample of bivalve, the pollution load index is being used to determine the degree of the contamination in the soft tissue of Marcia Marmorata and the result were showed in table 4 below.

\begin{tabular}{|c|c|c|c|c|c|c|}
\hline Stations & CFAs & CFCd & CFCu & CFZn & $\begin{array}{c}\text { Total CF } \\
(\mathrm{mg} / \mathrm{kg})\end{array}$ & $\begin{array}{c}\text { PLI index } \\
(\mathrm{mg} / \mathrm{kg})\end{array}$ \\
\hline Station 1 & 1.24 & 1.79 & 1.53 & 1.14 & 3.87 & 1.40 \\
\hline Station 2 & 1.28 & 1.00 & 1.00 & 1.00 & 1.28 & 1.06 \\
\hline Station 3 & 1.45 & 3.74 & 1.60 & 1.16 & 10.1 & 1.78 \\
\hline Station 4 & 1.00 & 2.74 & 1.66 & 1.50 & 6.82 & 1.62 \\
\hline
\end{tabular}

Table 4 Concentration Factor (CF) and Pollution Load Index values for bivalve tissue of Marcia Marmorata from study area.

The contamination factor (CF) of all metals in the study area was in moderately contaminated with range $(1 \leq$ $\mathrm{CF}<3$ ) but unfortunately, $\mathrm{CF}$ values for $\mathrm{Cd}$ at station 3 shows the highest value with $3.74 \mathrm{mg} / \mathrm{kg}$ and within the range $(3 \leq \mathrm{CF} \leq 6)$. This classified as considered contaminated. These higher values due to the influence of external discrete sources like industrial activities, agriculture runoff and other anthropogenic inputs (Adel Mashaan Rabee et al., 2011). The values of Pollution Load Index in table 5.0 were found to be generally higher and polluted $(>1)$ in all studied stations and this indicated deterioration of the site and estuarine quality (Mohiuddin et al., 2011) . These confirmed that Kuala Perlis Coastal Area is facing probable environmental pollution especially with dangerous heavy metal such as $\mathrm{Cd}$ which result from increased rate of non-treatment industrial waste which are discharged to Coastal area of Kuala Perlis.

Meanwhile, for sediment, the geo-accumulation index is being used to measure the degree of pollution in aquatic sediment and the result was in the table 5 below.

\begin{tabular}{|l|l|l|l|l|}
\hline Elements & As & Cd & Cu & Zn \\
\hline Station 1 & -10.46 & -0.81 & -0.94 & 0.33 \\
\hline Station 2 & -10.30 & -1.25 & -2.25 & 0.14 \\
\hline Station 3 & -10.47 & -1.51 & -1.94 & 0.00 \\
\hline Station 4 & -10.55 & -0.40 & 0.15 & -0.07 \\
\hline Average & -10.44 & -0.99 & -1.25 & 0.10 \\
\hline Standard dev & 0.11 & 0.49 & 0.94 & 0.18 \\
\hline
\end{tabular}

Table 5 Geo-accumulation index for studied heavy metal in sediment of Kuala Perlis.

From the table above, the geo-accumulation index for $\mathrm{As}, \mathrm{Cd}, \mathrm{Cu}$, and $\mathrm{Zn}$ were $(-10.44 \pm 0.11),(-0.99 \pm 0.49)$, ($1.25 \pm 0.94),(0.10 \pm 0.18)$ respectively. In average, $\mathrm{As}, \mathrm{Cd}$, and $\mathrm{Cu}$ remain in class 0 (unpolluted) in all stations suggesting that the study area sediments are in background value with respect to this metal. The I-geo for $\mathrm{Zn}$ at station 4 attains class 0 (unpolluted), while attain class 1 in other stations which indicates that sediments of these stations were uncontaminated to moderately contaminated by $\mathrm{Zn}$. From the data obtained, this suggest that the sediments of coastal area of Kuala Perlis, Perlis are having background concentrations for $\mathrm{As}, \mathrm{Cd}$ and $\mathrm{Cu}$, and these elements are practically unchanged by anthropogenic influences while the concentration of $\mathrm{Zn}$ exceeded the average shale value. Sorme et al. (2002) identified domestic construction and car related source and untreated waste water as the main sources of $\mathrm{Zn}$.

\section{Conclusion}

Overall research showed that heavy metal were exist in the sample of bivalve tissue of Marcia Marmorata sp. and sediment in certain level. The results conclude that that the level of $\mathrm{Zn}$ were highest in tissue of Marcia Marmorata and sediment when compare to $\mathrm{As}, \mathrm{Cd}, \mathrm{Cu}$ and $\mathrm{Zn}$ and exhibit the decreasing order of: $\mathrm{Zn}>\mathrm{Cu}>\mathrm{As}>\mathrm{Cd}$ while in sediment, the order was $\mathrm{Zn}>\mathrm{Cu}>\mathrm{Cd}>$ As. As recommendations, Sampling activity should be conducted frequently and seasonally during pre-monsoon, monsoon, and post-monsoon, as well as high and low tide in order to obtained different data and thus achieve accurate and more precise results. It is also suggested that this preliminary baseline data could be useful for regular heavy metal monitoring. However more 
studies such as genetics, taxonomic, laboratory, ecotoxicological and molecular are needed in establishing this mollusk species as a potential biomonitor in Malaysia coastal waters.

\section{References}

[1]. Adel Mashaan Rabee, Yaaroub Faleh Al-Fatlawy, Abd-Al-Husain Najim Abd own and Mustafa Nameer. Using Pollution Load Index (PLI) and Geoaccumulation Index (I-Geo) for the Assessment of Heavy Metals Pollution in Tigris River Sediment in Baghdad Region. Journal of Al-Nahrain University. Vol.14 (4), December, 2011, pp.108-114

[2]. Alfonso J.A, J. Azocar, J.J. LaBrecque, B. Garcia, D. Palacios \& Z. Benzo. 2008. Trace metals in bivalves and seagrass collected from Venezuelan coastal sites Rev. Biol. Trop. (Int. J. Trop. Biol. ISSN-0034-7744) Vol. 56 (Suppl. 1): $215-222$.

[3]. Alina, M., Azrina, A., Mohd Yunus, A.S., Mohd Zakiuddin, S., Mohd Izuan Effendi, H. and Muhammad Rizal, R. 2012. Heavy metals (mercury, arsenic, cadmium, plumbum) in selected marine fish and shellfish along the Straits of Malacca. International Food Research Journal 19(1): 135-140

[4]. Ahmad Ismail. The use of intertidal mollusk in the monitoring of heavy metals and organotin compounds in the west coast of Peninsular Malaysia. Coastal Marine Science 30(1): 401-406, 2006

[5]. Ahumada. R; Elizabeth González; Valentina Medina and Anny Rudolph. Analysis of mayor zinc sources in marine sediments of the estuarine zone in Aysén Fjord, Chile. Invest. Mar., Valparaíso, 35(2): 5-14, 2007.

[6]. Al-Yousuf, M.H., El-Shahawi, M.S., Al-Ghais, S.M., 2000. Trace metals in liver, skin and muscle of Lethrinus lentjan fish species in relation to body length and sex. Sci. Total Environ. 256, 87.

[7]. Andrew Rumsby., 2011., Significance of Arsenic in Sediment of Lake Rotoroa ( Hamilton Lake), Pattle De La ore Partners Ltd., Waikato Regional Council Technical Report 2011/18.

[8]. Chapman P. M., Wang, F. Y., Janssen, C., Persoone, G. and Allen, H. E., 1998. Ecotoxicology of metals in aquatic sediments: binding and release, bioavailability, risk assessment, and remediation. Can. J. Fiseries Aquat. Sci., 55, $2221-2243$.

[9]. Cobela-Garcia, A. and R. Prego, 2003. Heavy metal sedimentary record in a Glacian Ria (NW Spain): Background values and recent contamination. Mar.Pollut. Bull., 46: 1253-1262

[10]. El-Moselhy And Mohamed H. Yassien., (2005). Accumulation Patterns Of Heavy Metals In Venus Clams, Paphia Undulata (Born, 1780) And Gafrarium Pectinatum (Linnaeus, 1758), From Lake Timsah, Suez Canal, Egypt, Egyptian Journal Of Aquatic Research 1110-0354, Vol. 31, No.1 2005.

[11]. Fukunaga A ; Marti J Anderson., (2011). Bioaccumulation of copper, lead and zinc by the bivalves Macomona liliana and Austrovenus stutchburyi. Journal of Experimental Marine Biology and Ecology, Volume: 396, Issue: 2, Publisher: Elsevier B.V., Pages: 244-252

[12]. Hoda H.H. Ahdy and Azza Khaled. Heavy Metals Contamination in Sediments of the Western Part of Egyptian Mediterranean Sea. Australian Journal of Basic and Applied Sciences, 34):3330-3336,2009.

[13]. Inengite A.K; N. C. Oforka and Leo C. Osuji. Survey of heavy metals in sediments of Kolo creek in the Niger Delta, Nigeria. African Journal of Environmental Science and Technology Vol. 4(9), pp. 558-566, September 2010

[14]. Jahangir.S; Ghazala Siddiqui; Muhammad Moazzam; and Zarien Ayub.Clams of the families Tellinidae and veneridae and blood cockles of family arcidae from Phitti Creek and sonmiani along the coast of Pakistan (Northern Arabian Sea). Pakistan J.Zool ., vol 44(1),pp. 259-266,2012

[15]. Jain M.K, Dadhich L.K and Kalpana S. Heavy Metals Contamination in Sediments of the River Parbati, Baran, Rajasthan. Journal of Chemical, Biological and Physical Sciences. Vol.2. No.1, 54-60. Nov. 2011- Jan.2012.

[16]. Kamaruzzaman B.Y, M.S. Mohd Zahir, B. Akbar John, K.C.A. Jalal, S. Shahbudin, S.M. Al-Barwani and J.S. Goddard. Bioaccumulation of Some Heavy Metal by Green Mussel Perna Viridis (Linnaues 1758) from Pekan, Pahang, Malaysia. International Journal of Biological Chemistry 5(1): 54-60, 2011.

[17]. Lau S, Mohamed M, Tan Chi Yen.A, Su'ut. S., 1998. Accumulation of heavy metal in freshwater mollusc. The Science of the Total Environment $214,113-121$.

[18]. Liang L.N, B. Hea, G.B. Jianga,, D.Y. Chenb, Z.W. Yaoc., 2004. Evaluation of mollusks as biomonitors to investigate heavy metal contaminations along the Chinese Bohai Sea, Science of the total environment, Elsevier 324; 105-113

[19]. Mohiuddin K.M; Y. Ogawa; H. M. Zakir; K. Otomo; N. Shikazono. Heavy metals contamination in water and sediments of an urban river in a developing country. Int. J. Environ. Sci. Tech., 8 (4), 723-736, Autumn 2011.

[20]. Muohi AW, Onyari JM, Omondi JG, Mavuti KM (2003) Heavy metals in sediments from Makupa and Port-Reitz Creek systems: Kenyan Coast. Environ Int 28:619-647

[21]. Ndome, C.B., I.U. Udo, I.I. Akpan and C. Udom, 2011. Effect of water quality and bottom soil properties on the diversity and abundance of macrobenthic Fauna in some tropical frow-out earthen fish ponds. Ecologia, 2: 12-22.

[22]. Nur Atiqah Mohamad Yusoff and Shabdin Mohd Long. Comparative Bioaccumulation of Heavy Metals (Fe, Zn, Cu, Cd, Cr, Pb) in Different Edible Mollusk Collected from the Estuary Area of Sarawak River. UMTAS 2011.

[23]. Olade, M. A. (1987) Heavy Metal Pollution and the Need for Monitoring: Illustrated for Developing Countries in West Africa in T. C. Hutchinson and K. M. Meema (eds) Lead, Mercury, Cadmium and Arsenic in the Environment. SCOPE: John Wiley \& Sons Ltd.

[24]. Singh Y.T, Machina Krishnamoorthy and Seetharamaiah Thippeswamy. Status of heavy metals in tissues of wedge clam, Donax faba (Bivalvia: Donacidae) collected from the Panambur beach near industrial areas. Recent Research in Science and Technology 2012, 4(5): 30-35.

[25]. Silva, S.; Siqueira, J.O.; Soares, C.R.F.S. 2006. Mycorrhizal fungi influence on brachiariagrass growth and heavy metal extraction in a contaminatedsoil. Pesquisa Agropecuária Brasileira 41: 1749-1757. (in Portuguese, with abstract in English).

[26]. Sorme, L.; Lagerkvist, R., (2002). Sources of trace metals in urban wastewater in Stockholm. Sci. Total Environ., 298 (1-3), 131145 (15 pages).

[27]. Sofia. Metal Contamination In Commercially Important Fish And Shrimp Species Collected From Aceh (Indonesia), Penang And Perak (Malaysia). Universiti Sains Malaysia. 2005.

[28]. Velasquez, A.; Bechara, R.I.; Lewis, J.F.; et al. Glutathione replacement preserves the functional surfactant phospholipid pool size and decreases sepsis-mediated lung dysfunction in ethanol-fed rats. Alcoholism: Clinical and Experimental Research 26:1245$1251,2002$.

[29]. Wan Mohd Razi Idris; Sahibin Abdul Rahim; A.L.I. Zulfahmi Rahman; Tukiemat Lihan; Azman Hashim; Shahril Nlzam Mohd Yusuf (Geochemical Composition of Beach Sediment in Langkawi Island, Kedah, Malaysia) Sains Malaysiana 2009;38(3):313-320

[30]. Waznah S. Abdurahman, Kamaruzzaman Yunus \& Shahbudin Saad. 2011. Spatial and Temporal Variation of Zinc (Zn) and Cadmium (Cd) in the Bottom Sediments of Pahang River-estuary, Pahang, Malaysia. 
[31]. Yap, C.K., Tan, S.G., Ismail, A. and Omar, H. 2004. Allozyme polymorphisms and heavy metal levels in the green-lipped mussel Perna viridis (Linnaeus) collected from contaminated and uncontaminated sites in Malaysia. Environment International, 30 : 39-46.

[32]. Zhang L, Wang W-X. 2007. Gastrointestinal uptake of cadmium and zinc by a marine teleost Acanthopagrus schlegili. Aquatic Toxicology 85: 143-153.

\section{Acknowledgement}

Researchers want to thanks Ministry of Higher Education (MoHE) FRGS Grant 600-RMI/ST/FRGS 5/3/Fst (284/2010) for supporting this research. Besides that authors would like to appreciate the management of University Teknologi MARA, Perlis, MALAYSIA for the supporting us in conducting the research. 